\title{
Effect of caffeine on the intraocular pressure in patients with primary open angle glaucoma
}

This article was published in the following Dove Press journal:

Clinical Ophthalmology

I5 November 201।

Number of times this article has been viewed

\author{
Peeyush Chandra' \\ Ajit Gaur' \\ Shambhu Varma ${ }^{2}$ \\ 'Chandra Eye Research Institute, \\ Allahabad, UP, India; ${ }^{2}$ Department of \\ Ophthalmology and Visual Sciences, \\ University of Maryland School of \\ Medicine, Baltimore, MD, USA
}

Correspondence: Shambhu Varma Department of Ophthalmology and Visual Sciences, University of Maryland School of Medicine, 655 W Baltimore Street, Baltimore, MD, USA 2120|

Tel +I 4I0 7063395

Fax + I 4107067057

Email svarm00।@umaryland.edu
Purpose: Coffee and tea are very common nonalcoholic beverages. However, their intake, particularly that of coffee, has been suggested to increase intraocular pressure (IOP) in patients with open angle glaucoma/ocular hypertension. The causative agent has been suggested to be their caffeine content. The objective of this study was to determine if this represents a direct caffeine effect. This study was therefore done using pure caffeine applied directly to the eyes. Methods: The study was conducted with five human volunteers with open angle glaucoma/ ocular hypertension. IOP was measured using a Perkins applanation tonometer. Eye drops of $1 \%$ caffeine were prepared in-home. Following the initial (basal) measurement of the IOP, $50 \mu \mathrm{L}$ of the eye drop preparation was instilled in the eye at $0-, 4-$, and 6-hour intervals. IOPs were measured 30 minutes after each instillation. A second study was also undertaken following the first. In this study, the same patients instilled the eye drops three times per day for 1 week at home and then returned to the clinic on day 7 . They were then again treated with caffeine eye drops as above and IOPs measured.

Results: In the 1-day study, the mean basal IOP was $23.6 \pm 2.80 \mathrm{mmHg}$. Thirty minutes after instillation of the drops as described, the pressures were $23.2 \pm 1.93,22.2 \pm 1.99$, and $22.6 \pm 2.31$. The basal reading was taken at $10 \mathrm{am}$ and another reading was then taken at $10.30 \mathrm{am}$. Additional eye drops were instilled at 2 and $8 \mathrm{pm}$ and readings taken 30 minutes after each instillation. In the 1 week study, the basal value was $22.6 \pm 2.32$. After instillation of the drops as above the values were $23 \pm 2.16,22.4 \pm 2.27$, and $23 \pm 1.94$.

Conclusion: Administration of caffeine into the eyes of patients did not have any effect on IOP and it remained relatively unchanged. This was true in the 1-day study as well as in the 1-week study. A cumulative effect was not visible. The results therefore demonstrate that caffeine has no significant effect on IOP in patients with glaucoma. Any effects reported in coffee drinkers may therefore be related to other constituents in coffee, known to be generated pyrolytically from endogenous constituents of coffee beans by roasting at relatively high temperature, combined with the osmotic effects imposed by adequate fluid intake, known to be common in glaucoma patients.

Keywords: caffeine, open angle glaucoma, intraocular pressure, ocular hypertension

\section{Introduction}

Caffeine (1,3,7-trimethylxanthine) is a significant ingredient in several common beverages such as coffee, tea, and colas, as well as in various other food items such as cakes and candies. A regular cup of coffee (236 mL) contains $135-150 \mathrm{mg}$ of caffeine. ${ }^{1}$ On average, daily consumption from normal coffee drinking alone is over $200 \mathrm{mg}$ per day, although amounts up to $400 \mathrm{mg}$ per day have been reported from certain European countries. ${ }^{2,3}$ Such amounts of caffeine are known to exert several physiological effects 
such as stimulation of the central nervous system (CNS), cardiac excitation, relaxation of bronchial and vascular smooth muscles, and promotion of diuresis and intestinal motility. ${ }^{4,5}$

Although most of these caffeine effects are ultimately related to its effect of increasing levels of cytosolic calcium ions, the specific mechanisms involved and the magnitude of the physiological effects differ from one tissue to another. Stimulation of the CNS, for example, is attributed to a competitive blockade of the adenosine receptors situated at the presynaptic nerve terminals. ${ }^{6-9}$ This is due to the structural similarities between adenosine and caffeine, both purine derivatives. Since the binding of adenosine to its receptor regulates the voltage-gated calcium channels, blockade of these receptors results in an increased influx of calcium from the extracellular milieu into the cell cytosol, causing an increase in the synaptic release of neurotransmitters, including acetylcholine, norepinephrine, dopamine, and others involved in neural transduction and cardiovascular stimulation. ${ }^{9-11}$

The stimulation of cardiac muscle contraction by caffeine ${ }^{12-14}$ has been attributed to its binding with ryanodinesensitive $\mathrm{Ca}^{++}$channels in the sarcoplasmic reticulum ${ }^{15-18}$ and consequent release of the sequestered $\mathrm{Ca}^{++}$into the cytosol. In turn, the increased cytosolic $\mathrm{Ca}^{++}$stimulates muscle contraction via interaction with the actomyosin complex.

The vasodilatory effect of $\mathrm{Ca}^{++}$is exerted through $\mathrm{Ca}^{++}$-dependent activation of nitric oxide synthase, resulting in the elevation of nitric oxide and cyclic guanosine monophosphate levels. ${ }^{19}$ Caffeine also has several metabolic effects $^{20-23}$ exerted through an inhibition of cyclic adenosine monophosphate (c-AMP) phosphodiesterase ${ }^{24}$ leading to an enhancement of c-AMP levels in the cells.

In summary, most of the neural and extraneural effects of caffeine are exerted through its action on intracellular levels of free calcium and inhibition of phosphodiesterase. However, several recent biochemical studies demonstrate that it is also an effective scavenger of reactive oxygen species, including the hydroxyl radical $\mathrm{OH}^{\bullet} .{ }^{25-33}$ The product of such a reaction is the formation of the 8-oxo derivative of caffeine, known as N-trimethyl urate. However, direct generation of $\mathrm{OH}^{\bullet}$ in vivo is a rarity. Usually it takes place by the interaction of hydrogen peroxide and superoxide, which by themselves are potent oxidants, detoxified normally by superoxide dismutase, catalase, and glutathione peroxidase. The generation of $\mathrm{OH}^{\bullet}$ is hence greatly minimized in most tissues, except in the cases of the eye and the skin where its generation remains consistent via several photochemical reactions. ${ }^{29}$

Studies on the pathophysiological effects of caffeine in the eye are still very limited. However, coffee drinking has been suggested to cause a transient elevation of intraocular pressure (IOP) in patients with glaucoma. The magnitude of such pressure elevation ranges from 1 to $2 \mathrm{mmHg}$, an hour after drinking coffee. ${ }^{34-37}$ The significance of this relatively small elevation in the face of a normal IOP of 14-22 mmHg remains unsure, especially in view of a number of studies that have found no such effect. ${ }^{38-40}$ In fact, it is well known that such increases can take place just by drinking equivalent amounts of water, ranging from 250 to $1000 \mathrm{~mL} .{ }^{41-47}$ That normal coffee drinking is not associated with an effect on IOP has been shown also by a large cohort study. ${ }^{48}$ Further, it should be pointed out that coffee is not analogous to caffeine, ${ }^{49}$ the former being a complex mixture of compounds containing several other physiologically active compounds such as furfurals and acrolein.

Information about the effect of caffeine per se on IOP in patients with glaucoma/ocular hypertension is not yet available, except for one study where oral administration of caffeine was found to be ineffective in raising IOP. ${ }^{50}$ However, such studies are still lacking in glaucoma patients, who are known to have significant alterations in aqueous dynamics and IOP. The effect of a continued supply of caffeine to the aqueous humor also remains to be studied to determine whether there are any cumulative effects.

A study of the effects of direct topical application of caffeine on IOP in patients with glaucoma was thus desirable, especially in view of the many recent observations strongly suggesting that the compound has significant positive health effects such as the prevention of diseases such as Alzheimer's and Parkinson's-like diseases, ${ }^{51-58}$ and inhibition of the onset of diabetes..$^{59,60}$ This study was therefore undertaken to determine the effect of caffeine on IOP in patients with glaucoma/ ocular hypertension, using direct topical administration of pure caffeine via eye drops, eliminating the possibility of indirect metabolic effects.

Contrary to expectations based on earlier observations of coffee drinking in relation to IOP in glaucoma patients, the results of this study indicate that direct application of caffeine to the eye does not exert any effect on IOP. This applied both in studies done within hours of caffeine instillation in the eye and when patients were treated consecutively 3 times a day for 6 days followed by another treatment on day 7 . The authors' studies suggest no reason for caution in the use of 
caffeine in patients with open angle glaucoma, as similar small increases in IOP can be generated by water-drinking as seen in a provocative test for glaucoma. This is attributable to changes in body fluid osmotic dynamics.

\section{Materials and methods}

A $1 \%$ caffeine eye drop preparation was made by dissolving $100 \mathrm{mg}$ of caffeine (Sigma Aldrich catalogue number 58082; Sigma Aldrich, St Louis, MO) in $10 \mathrm{~mL}$ of sterile teardrop solution ( $0.3 \%$ hydroxyl-propyl methyl cellulose) (Sigma Aldrich) at room temperature. The solution was then divided, using sterile techniques, into $1 \mathrm{~mL}$ portions in eye drop vials and refrigerated. IOP was determined using a Perkins applanation tonometer (Clement Clarke Perkins MK-II; Clement Clarke International, Harlow, UK) after application of procaine/fluorescein eye drops (Smarth Life Sciences Nalagarh, Solan, Himachal Pradesh, India).

The five volunteers selected for the study were diagnosed to have primary open angle glaucoma/ocular hypertension. The age of the patients varied from 40 to 65 years. The group mean IOP was $23.6 \pm 2.8 \mathrm{mmHg}$. They had not had any ocular surgical procedures such as cataract extraction or laser photocoagulation treatment for retinopathy.

Basal intraocular pressures were taken at 10.00 am and labeled "A." Immediately following, the caffeine eye drop preparation was instilled $(50 \mu \mathrm{L})$ and the eye closed for proper mixing of the drop in the conjunctival cul-de-sac. An IOP measurement was then taken at 10.30 am (labeled "B"). Additional eye drops were then instilled in the respective eyes at 2 and $8 \mathrm{pm}$ and IOP measured again 30 minutes after each instillation, that is, at 2.30 (C) and $8.30 \mathrm{pm}$ (D), respectively. Thus, the total number of IOP measurements on each eye was four, including the initial basal reading. Blood pressures were taken at the beginning and at the end of the investigation, with no substantial change revealed. Subsequently, the patients were asked to instill the eye drops three times daily at the above times for 6 days and then return to the clinic on day 7 . The above schedule of drop instillation and IOP measurements was then repeated. The patients were then withdrawn from the study and started on antiglaucoma medications.

\section{Results}

The initial mean IOP level in the volunteers prior to caffeine drop instillation was $23.6 \pm 2.8 \mathrm{mmHg}$. The levels 30 minutes after each subsequent treatment were $23.2 \pm 1.93,22.2 \pm 1.99$, and $22.6 \pm 2.31 \mathrm{mmHg}$,
Table I Effect of caffeine eye drops on intraocular pressure: I-day treatment study

\begin{tabular}{lllll}
\hline & A & B & C & D \\
\hline Mean IOP & 23.6 & 23.2 & 22.2 & 22.6 \\
Standard deviation & 2.8 & 1.93 & 1.99 & 2.31 \\
$t$ with A reference & & 0.37 & 1.3 & 0.87 \\
Variance $(\mathrm{p}) / \mathrm{A}^{*}$ & & 0.71 & 0.21 & 0.4 \\
\hline
\end{tabular}

Notes: $(\mathbf{A})$ represents the basal IOPs $(\mathrm{mmHg})$. (B) represents the values soon after the first treatment. To look for a possible cumulative effect, eye drop instillation was repeated after 4 hours $(\mathbf{C})$ and 6 hours (D) and IOP determined 30 minutes after each administration. The total number of eyes was ten, using the right as well the left eyes of five subjects. Contralateral difference was $1.4 \pm 0.69 \mathrm{mmHg}$. *Variance (p) of the IOPs under $B, C$, and D with referece to the IOP under A, based on the corresponding $t$ values indicated above.

Abbreviation: IOP, intraocular pressure.

respectively. As summarized in Figure 1, no significant effect from the caffeine drops was noticeable. Repeated drop instillation did not show any enhancement of IOP. Blood pressure levels also remained unaffected. The results of the initial 1-day study were statistically analyzed and are summarized in Table 1 .

To examine the possibility of any long-term effect of caffeine administration, the above study was extended by asking the patients to use the caffeine drops 3 times a day for 6 additional days, as per schedule used during the initial 1-day study, and return to the clinical on day 7 for further pressure measurements. On their return, the patients did not report any unwanted effects except for a general feeling of well-being. Measurement of IOP and caffeine administration was repeated on return as above. The results of this second investigation were statistically analyzed and are summarized in Table 2 (see also Figure 2, a bar diagram for easier comprehension). "A" represents the basal readings obtained without any further treatment with the caffeine eye drops. "B," "C," and " $\mathrm{D}$ " represent the data after caffeine administration as described above for the 1-day investigation. Contrary to

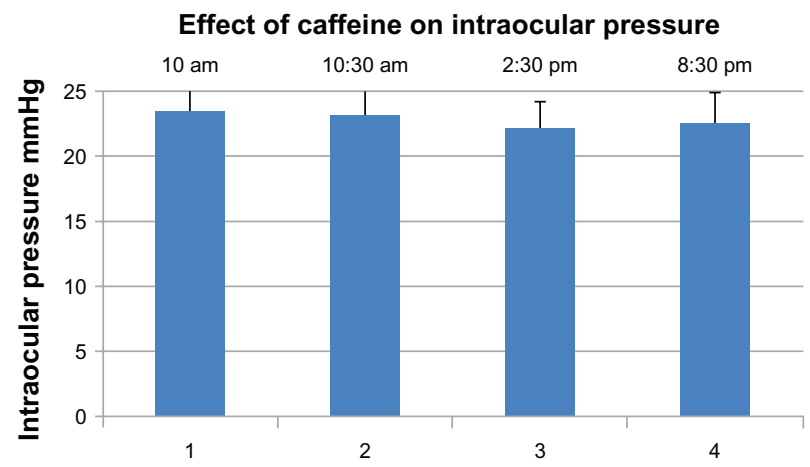

Figure I The bars represent the intraocular pressure of patients given caffeine eye drops as described for Table I (the I-day study).

Notes: The times indicated sequentially represent measurements $\mathbf{A}$ to $\mathbf{D}$. The extended lines on the bar represent standard deviations. 
Table 2 Effect of caffeine eye drops on intraocular pressure: I-week study

\begin{tabular}{lllll}
\hline Groups & A & B & C & D \\
\hline Mean IOP & 22.6 & 23.0 & 22.4 & 23.0 \\
Standard deviation & 2.32 & 2.16 & 2.27 & 1.94 \\
t with A reference & & 0.39 & 0.19 & 0.48 \\
Variance (p)/A & & 0.69 & 0.85 & 0.68 \\
\hline
\end{tabular}

Note: After 6 days of 3 times daily application, the procedure described in Table 1 was repeated with identical times of drop instillation and IOP measurements. The total number of eyes remained at ten, using the right as well the left eyes of five subjects. Contralateral difference was $1.3 \pm 0.99 \mathrm{mmHg}$.

expectations, no increase or decrease of IOP was noticed even in this study. The individual basal readings, as well as those determined 30 minutes after administering the drops, remained essentially unchanged. The reading in the group before administration of any drops was $22.6 \pm 2.32 \mathrm{mmHg}$. This was similar to that obtained in the 1-day experiment, which was $23.6 \pm 2.8$. Subsequent readings at the above time points were $23,22.4$, and $23 \mathrm{mmHg}$, respectively, indicating no change in IOP after caffeine drop treatment.

\section{Discussion}

Caffeine is widely present in various beverages and food items. Medically, it is frequently used as a CNS stimulant and for treating asthma and apnea, the latter primarily in preterm infants. ${ }^{4}$ The US Food and Drug Administration lists this compound as generally safe for human consumption, the median lethal dose being high (10-15 $\mathrm{g}$ in a single dose), which is equivalent to 80-100 cups of coffee. Achieving lethality is difficult. Additionally, regular use of this compound, mostly from coffee or other common beverages, has been reported to provide several very significant health benefits such as reduced incidence of Alzheimer's and Parkinson's diseases, ${ }^{51-56}$ senile dementia, and prevention of neural degeneration in general which is associated

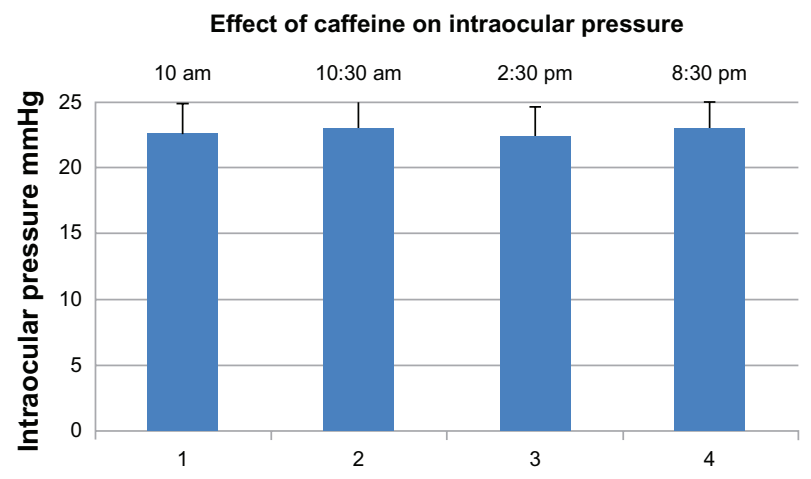

Figure 2 The bars represent the intraocular pressure on patients given caffeine eye drops as described under Table 2, (the I week study).

Notes: The times indicated sequentially represent measurements $\mathbf{A}$ to $\mathbf{D}$. The extended lines on the bar represent standard deviations. with loss of cognitive performance. ${ }^{57,58}$ Recent reports also suggest that caffeine decreases the risk of development of type 2 diabetes, ${ }^{59,60}$ loss of liver function and cirrhosis, ${ }^{61,62}$ and development of certain cancers. ${ }^{63-68}$

Previous reports suggesting an association between regular use of caffeine and development of hypertension have been significantly toned down in view of recent epidemiological findings. ${ }^{69}$ The association between hypertension and coffee intake could not be established in a study based on at least 155,000 nurses. ${ }^{70}$ A Harvard study of 128,000 people concluded that coffee consumption is not associated with coronary heart disease unless it is used in combination with cigarette smoking and excessive use of alcohol. These and many other positive reports, including caffeine's biochemical properties of scavenging reactive oxygen species, strongly suggest the desirability of further studies regarding its effect on the pathophysiology of ocular diseases. Based on earlier suggestions of possible transient increase in blood pressure caused by caffeine in persons who are not habitual users, ${ }^{4}$ it was speculated that the caffeine present in coffee might also increase IOP, as a hemodynamic effect. A transient increase of 1-2 mmHg pressure following coffee drinking has indeed been found to be the case in some reports ${ }^{34-36}$ but not in others. $^{37-40}$ The pathophysiological significance of such a small change, if true, remains to be established.

Coffee is not analogous to caffeine. ${ }^{49}$ Therefore, attributing the effects of coffee drinking on IOP elevation solely to coffee's caffeine content may be misleading, because coffee contains several other physiologically active substances derived from the coffee beans endogenously, as well as those produced during its processing by roasting and the preparation of the drink itself. Roasted coffee beans are known to contain several bioactive ingredients such as furfural and its derivatives, formaldehyde, and acrolein, ${ }^{71,72}$ just to mention a few that are all known to be toxic to the eye. ${ }^{73}$ Their concentrations also differ. It is therefore difficult to exclude the possibility that variation in the levels of these constituents in different coffee brands and preparations might have been responsible for the differences in results reported on IOP in coffeedrinking patients. This limitation applies even in studies where tea, with lower amounts of caffeine $(\sim 3 \mathrm{mg})$, was used as a control. Its composition is very different to that of coffee beans. It was therefore necessary to investigate the effect of caffeine on IOP in glaucoma patients by topical application of the chemically pure compound. Additional studies were also considered important because several recent studies suggest that caffeine appears beneficial to ocular tissues by protecting them against $\mathrm{OH}^{\bullet}$ radical-induced oxidative stress. 
In addition, caffeine can support the tissues metabolically by inhibiting c-AMP phosphodiesterase and thereby maintaining c-AMP levels. ${ }^{74-76}$ Caffeine's effect in boosting body ergonomics and memory is now well accepted.

The observed ineffectiveness of caffeine in elevating IOP is not due to any lower doses than can be derived from drinking coffee. The amount used was much higher than that achievable by coffee drinking. The peak plasma level of caffeine following coffee drinking, 1 hour after consumption, varies from 3 to $12 \mathrm{mg} / \mathrm{L} .{ }^{77}$ Being freely diffusible, this level will be similar in intraocular fluids including the aqueous humor. The initial amount of caffeine instilled in the eyes in these experiments was $0.5 \mathrm{mg}$ present in $50 \mu \mathrm{L}$ of the drop preparation. On closing the eye after instillation, most of it leaked out through the palpebral fissure and nasolacrimal pathway, so about $8-10 \mu \mathrm{L}$ was retained in the conjunctival sac. Hence, at maximum, a bolus of $0.1 \mathrm{mg}$ of caffeine remains available to equilibrate with the aqueous, with the instant theoretical level of $0.5 \mathrm{mg} / \mathrm{mL},(4.5 \mathrm{mM})$, taking the aqueous volume to be $\sim 0.2 \mathrm{~mL}$. Topical instillation of such caffeine drops elevates the aqueous level significantly, as predicted above and as has been shown previously in experiments with rats. ${ }^{78}$

In summary, therefore, studies with pure caffeine convincingly demonstrate that caffeine does not have any significant effect on IOP in patients with glaucoma/ocular hypertension, as is the case in humans without glaucoma/ ocular hypertension given oral doses of caffeine. ${ }^{50}$

\section{Disclosure}

The authors report no conflicts of interest in this work.

\section{References}

1. Barone JJ, Robert HR. Caffeine consumption. Food Chem Toxicol. 1996;34:119-129.

2. wiseGeek. How much caffeine is consumed by the average person? [Web page on the Internet.] Sparks, NV: wiseGeek; nd. Available from: http:// www.wisegeek.com/how-much-caffeine-is-consumed-by-the-averageperson.htm. Accessed September 13, 2011.

3. Energy Fiend. Caffeine: consumption by country [web page on the Internet]. Energy Fiend; nd [updated August 18, 2011]. Available from: http://www.energyfiend.com/caffeine-what-the-world-drinks. Accessed September 13, 2011.

4. Serafin WE. In: Hardman JG, Limbird LE, Molinoff PB, Ruddon RW, Goodman Gillman A, editors. Goodman and Gillman's Pharmacological Basis of Therapeutics. 9th edition. New York: McGraw Hill; 1996: 673-679.

5. Arnaud MJ. The pharmacology of caffeine. Prog Drug Res. 1987;31: 273-313.

6. Wilson DF. Effect of caffeine on neuromuscular transmission in rats. Am J Physiol. 1973;225(4):862-865.

7. Daly JW, Burns RF, Snyder SH. Adenosine receptor in the central nervous system; Relationship to the central actions of methylxanthines. Life Sci. 1981;28(19):2083-2097.
8. Dunwiddie TV. Interactions between the effects of adenosine and calcium on synaptic responses in rat hippocampus in vitro. $J$ Physiol. 1984;350:545-559.

9. Morgan MD, Vestal RE. Methylxanthine effects on caudate dopamine release as measured by in vivo electrochemistry. Life Sci. 1989;45:2025-2039.

10. Pedata F, Giovanelli L, De Samo P, Pepeu B. Effect of adenosine derivatives and caffeine on acetylcholine release from the brain synaptosomes: Interaction with muscarinic autoregulatory mechanisms. J Neurochem. 1986;46(5):1593-1598.

11. Solinas M, Ferre S, You ZB, Karcz-Kubicha M, Popoli P, Goldberg SR. Caffeine induces dopamine and glutamate release in the shell of the nucleus accumbens. J Neurosci. 2002;22(15):6321-6324.

12. Degubareff $\mathrm{T}$, Sleator W Jr. Effects of caffeine on $\mathrm{t}$ mammalian atrial muscle and its interaction with adenosine and calcium. J Pharmacol Exp Ther. 1965;148:202-214.

13. Blinks JO, Olson CB, Jewell BR, Braveny P. Influence of caffeine and other methyl xanthines in the mechanical properties of isolated mammalian heart muscle. Circ Res. 1972;30(4):367-392.

14. Dobemeyer JJ, Stein RA, Leier RA, Greenberg R, Schaal SF. The arrythmogenic effects of caffeine in human beings. $N$ Engl $J$ Med. 1983;308(14):814-816.

15. Ogawa Y, Ebashi S. Ca-Releasing action of $\beta \gamma$-methylene adenosine triphosphate on fragmented sarcoplasmic reticulum. $J$ Biochem. 1976;80(5):1149-1157.

16. Rousseau E, Ladine J, Liu QY, Meissner G. Activation of Ca2+ release channel of skeletal muscle sarcoplasmic reticulum by caffeine and related compounds. Arch Biochem Biophys. 1988;267(1):75-86.

17. Bhat MB, Zhao J, Zang W, et al. Caffeine-induced release of intracellular $\mathrm{Ca} 2+$ from Chinese hamster ovary cells expressing skeletal muscle ryanodine receptor. Effects on full length carboxyl-terminal portion of Ca2+ release channels. J Gen Physiol. 1997;110(6):749-762.

18. Coronado R, Morrissette J, Sukhareva M, Vaughan DM. Structure and function of ryanodine receptors. Am J Physiol. 1994;226(6 Pt 1): C1485-C1504.

19. Echeverri D, Montes FR, Cabrera M, Galan A, Prieto A. Caffeine's vascular mechanisms of action. Int J Vasc Med. 2010;2010:834060.

20. Acheson KH, Zahorska-Mickiewicz B, Pittet P, Anantharaman K, Jequier E. Caffeine and coffee: their influence on metabolic rate and substrate utilization in normal weight and obese individuals. Am J Clin Nutr. 1980;33(5):989-997.

21. Bauer J, Maier K, Linderkamp O, Hentschel R. Effects of caffeine on oxygen consumption and metabolic rate in very low birth weight infants with idiopathic apnea. Pediatrics. 2001;107(4):660-663.

22. Belza A, Toubro S, Astrup A. The effect of caffeine, green tea and tyrosine on thermogenesis and energy intake. Eur J Clin Nutr. 2009;63(1):57-64.

23. Yeo SE, Jentjens RL, Wallis GA, Jeukendrup AE. Caffeine increases exogenous carbohydrate oxidation during exercise. J Appl Physiol. 2005;99(3):844-850.

24. Beavo JA, Rogers NL, Crofford OB, Hardman JG, Sutherland WW, Newman EV. Effect of xanthine derivatives on lipolysis and on adenosine 3',5'-monophosphate phosphodiesterase activity. Mol Pharmacol. 1970;6(6):597-603.

25. Shi X, Dalal NS, Jain AC. Antioxidant behavior of caffeine: efficient scavenging of hydroxyl radicals. Food Chem Toxicol. 1991;29(1):1-6.

26. Stadler RH, Fay LB. Antioxidative reactions of caffeine: formation of 8-oxocaffeine (1,3,7 trimethyl uric acid) in coffee subjected to oxidative stress. J Agric Food Chem. 1995;43:1332-1338.

27. Devasagayam TP, Kamat JP, Mohan H, Kesavan PC. Caffeine as an antioxidant: inhibition of lipid peroxidation induced by reactive oxygen species. Biochim Biophys Acta. Bio membranes. 1996;1282(1): 63-70.

28. Stadler RH, Richoz J, Turesky RJ, Welti DH, Fay LB. Oxidation of caffeine and related methylxanthines in ascorbate and polyphenol-driven Fenton-type oxidations. Free Radic Res. 1996;24(3): $225-240$. 
29. Varma SD, Kumar S, Richards RD. Light-induced damage to ocular lens cation pump: prevention by vitamin C. Proc Natl Acad Sci USA. 1979;76(7):3504-3506.

30. Chung WG, Cha YN. Oxidation of caffeine to theobromine and theophylline is catalyzed primarily by flavin-containing monooxygenase in liver microsomes. Biochem Biophys Res Commun. 1997;235(3): 685-688.

31. Dalmazio I, Santos LS, Lopes RP, Eberlin MN, Augusti R. Advanced oxidation of caffeine in water: On-line and real-time monitoring by electrospray ionization mass spectrometry. Environ Sci Technol. 2005;39(16):5982-5988.

32. Telo JP, Vieira AJ. Mechanism of free radical oxidation of caffeine in aqueous solution. J Chem Soc Perkin Trans. 1997;2:1755-1757.

33. Varma SD, Kovtun S, Hegde K. Role of ultraviolet irradiation and oxidative stress in cataract formation: medical prevention by nutritional antioxidants and metabolic agonists. Eye Contact Lens. 2011;37(4):233-245.

34. Higginbotham EJ, Kilimanjaro HA, Wilensky JT, Batenhorst RL, Hermann D. The effect of caffeine on intraocular pressure in glaucoma patients. Ophthalmology. 1989;96(5):624-626.

35. Avisar R, Avisa E, Weinberger D. Effect of coffee consumption on intraocular pressure. Ann Pharmacother. 2002;36(6):992-995.

36. Leydhecker W. Glaukom, ein Handbuch [Handbook of Glaucoma]. Berlin: Springer-Verlag; 1960.

37. Peczon JD, Grant WM. Sedatives, stimulants, and intraocular pressure in glaucoma. Arch Ophthalmol. 1964;72:178-188.

38. Chandrasekaran S, Rochtchina E, Mitchell P. Effect of caffeine on intraocular pressure: The Blue Mountains Eye Study. J Glaucoma. 2005;14(6):504-507.

39. Jim and Looker [Internet pseudonyms]. Caffeine and ocular pressure? MedKB.com [forum on the Internet]. MedKB; November 2003. Available from: http://www.medkb.com/Uwe/Forum.aspx/glaucoma/97/ Caffiene-and-occular-pressure. Accessed September 13, 2011.

40. Wilensky JT. Glaucoma. Eye Facts [website on the Internet]. Chicago, IL: University of Illinois Department of Ophthalmology and Visual Sciences; November 10, 2010. Available from: http://www.uic.edu/ com/eye/LearningAboutVision/EyeFacts/Glaucoma.shtml. Accessed September 13, 2011.

41. Leydhecker W. The water-drinking test. British J Ophthalmol. 1950;34(8):457-479.

42. Buckingham T, Young R. The rise and fall of intra-ocular pressure; the influence of physiological factors. Ophthalmic Physiol Opt. 1986;6(1):95-99.

43. Drance SM. Studies with applanation water tests. Arch Ophthalmol. 1963;69:39-43.

44. Moura MA, Rodrigues LO, Waisberg Y, De Almeida HG, Silami-Garcia E. Effects of submaximal exercise with water ingestion on intraocular pressure in healthy human males. Braz J Med Biol Res. 2002;35(1):121-125.

45. Armaly MF, Sayegh RE. Water-drinking test. II. The effect of age on tonometric and tonographic measures. Arch Ophthalmol. 1970;83(2):176-181.

46. Alimuddin M. Normal intra-ocular pressure. BrJOphthalmol. 1956;40(6): 366-372.

47. Agarwal LP, Sharma CK. Two provocative tests for glaucoma. $B r J$ Ophthalmol. 1955;37(6):330-335.

48. Kang JH, Willet WC, Rosner BA, Hankinson SE, Pasquale LR. Caffeine consumption and the risk of primary open-angle glaucoma: a prospective cohort study. Invest Ophthalmol Vis Sci. 2008;49(5):1924-1931.

49. Illy E. The complexity of coffee. Scientific American. 2002;286(6): 86-91.

50. Adams BA, Brubaker RF. Caffeine has no clinically significant effect on aqueous humor flow in the normal human eye. Ophthalmology. 1990;97(8):1030-1031.

51. Maia L, de Mendonça A. Does caffeine intake protect from Alzheimer's disease? Eur J Neurol. 2002;9(4):377-382.
52. Lindsay J, Laurin D, Verreault R, et al. Risk factors for Alzheimer's Disease: a prospective analysis from the Canadian Study of Health and Aging. Am J Epidemiol. 2002;156(5):445-453.

53. Institute of Holistic Nutrition. Caffeine anyone? Available at:http:// www.sciencedaily.com/releases/2009/01/090114200005.htm.

54. Ritchie K, Carriere I, de Mendonca A, et al. The neuroprotective effects of caffeine: a prospective population study (the Three City Study). Neurology. 2007;69(6):536-545.

55. Ross GW, Abbott RD, Petrovich H, et al. Association of coffee and caffeine intake with the risk of Parkinson disease. JAMA. 2000;283(20):2674-2679.

56. Benedetti MD, Bower JH, Maraganore DM, et al. Smoking, alcohol, and coffee consumption preceding Parkinson's disease. Neurology. 2000;55(9):1350-1358.

57. Jarvis MJ. Does caffeine intake enhance absolute levels of cognitive performance? Psychopharmacology. 2005;110(1-2):45-52.

58. Johnson-Kozlow M, Kritz-Silverstein D, Barrett-Connor E, Morton D. Coffee consumption and cognitive function among older adults. Am J Epidemiol. 2002;156(9):842-850.

59. Salazar-Martinez E, Willett WC, Ascherio A, et al. Coffee consumption and risk for type 2 diabetes mellitus. Ann Intern Med. 2004;140(1):1-8.

60. Huxley R, Lee CM, Barzi F, et al. Coffee, decaffeinated coffee, and tea consumption in relation to incident type 2 diabetes mellitus: a systematic review with meta-analysis. Arch Intern Med. 2009;169(22):2053-2063.

61. Klatsky AL, Morton C, Udaltsova N, Friedman GD. Coffee, cirrhosis, and transaminase enzymes. Arch Intern Med. 2006;166(11):1190-1195.

62. Cadden IS, Partovi N, Yoshida EM. Review article: possible beneficial effects of coffee on liver disease and function. Aliment Pharmacol. 2007;26(1):1-8.

63. Inoue M, Yoshimi I, Sobue T, Tsugane S. JPHC Study Group. Influence of coffee drinking on subsequent risk of hepatocellular carcinoma: a prospective study in Japan. J Natl Cancer Inst. 2005;97(4): 293-300.

64. Rodriguez T, Altieri A, Chatenoud L, et al. Risk factors for oral and pharyngeal cancer in young adults. Oral Oncol. 2004;40(2): 207-213.

65. Tavani A, Bertuzzi M, Talamini R, et al. Coffee and tea intake and risk of oral, pharyngeal and esophageal cancer. Oral Oncol. 2003;39(7):695-700.

66. Song YJ, Kristal AR, Wicklund KG, Cushing-Haugen KL, Rossing MA. Coffee, tea, colas, and risk of epithelial ovarian cancer. Cancer Epidemiol Biomarkers Prev. 2008;17(3):712-716.

67. Ganmaa D, Willett WC, Li TY, et al. Coffee, tea, caffeine and risk of breast cancer: a 22-year follow-up. Int J Cancer. 2008;122(9):2071-2076.

68. Flatow J, Wilson K. can coffee lower the risk of prostate cancer [Transcript.] National Public Radio. December 11, 2009. Available at: http:// www.npr.org/templates/story/story.php?storyId=121343438. Accessed September 21, 2011.

69. Cromie W. Coffee gets cleared of blood pressure risk. Harvard Gazette. Nov 2005;10:2006. Available at: http://www.news.harvard.edu/ gazette/2005/11.10/06-coffee.html.

70. Lopez-Garcia E, van Dam RM, Willett WC, et al. Coffee consumption and coronary heart disease in men and women: a prospective cohort study. Circulation. 2006;113(17):2045-2053.

71. Rizzi GP. Formation of sulfur-containing volatiles under coffee roasting. In: Parliament TH, Ho CT, Schieberle. Caffeinated Beverages: Health Benefits, Physiological Effects, and Chemistry. ACS Symposium Series, Vol 754. Washington, DC: American Chemical Society; 2000:210-215.

72. Quarta B, Anese M. Furfurals removal from roasted coffee powder by vacuum treatment. Food Chem. 2011;130:610-614.

73. Grant WM. Toxicology of the Eye. 2nd ed. Springfield Illinois: Charles C Thomas; 1974:590, 502.

74. Varma SD, Hegde KR. Prevention of oxidative damage to lens by caffeine. J Ocul Pharmacol Ther. 2010;26(1):73-77. 
75. Varma SD, Hegde KR. Kynurenine-induced photo oxidative damage to lens in vitro: protective effect of caffeine. Mol Cell Biochem. 2010;340(1-2):49-54.

76. Wang L, Lu L. Pathway-specific effect of caffeine on protection against UV irradiation-induced apoptosis in corneal epithelial cells. Invest Ophthalmol Vis Sci. 2007;48(2):652-660.
77. Baselt R. Disposition of Toxic Drugs and Chemicals in man. (9th ed.) Seal Beach, CA: Biomedical Publications; 2011.

78. Varma SD, Kovtun S, Hegde K. Effectiveness of topical caffeine in cataract prevention: studies with galactose cataract. Mol Vis. 2010;16:2626-2633.

\section{Clinical Ophthalmology}

\section{Publish your work in this journal}

Clinical Ophthalmology is an international, peer-reviewed journal covering all subspecialties within ophthalmology. Key topics include: Optometry; Visual science; Pharmacology and drug therapy in eye diseases; Basic Sciences; Primary and Secondary eye care; Patient Safety and Quality of Care Improvements. This journal is indexed on

Submit your manuscript here: http://www.dovepress.com/clinical-ophthalmology-journal
Dovepress

PubMed Central and CAS, and is the official journal of The Society of Clinical Ophthalmology (SCO). The manuscript management system is completely online and includes a very quick and fair peer-review system, which is all easy to use. Visit http://www.dovepress.com/ testimonials.php to read real quotes from published authors. 